Métis Issueson @IndigenousXca

\author{
Adam Gaudry \\ Assistant Professor, Department of Indigenous Studies, University of Saskatchewan
}

aboriginal policy studies Vol. 5, no. 1, 2015, pp. 94-107

This article can be found at:

http://ejournals.library.ualberta.ca/index.php/aps/article/view/25646

ISSN: $1923-3299$

Article DOI: http://dx.doi.org/10.5663/aps.v5i1.25646

aboriginal policy studies is an online, peer-reviewed and multidisciplinary journal that publishes original, scholarly, and policy-relevant research on issues relevant to Métis, non-status Indians and urban Aboriginal people in Canada. For more information, please contact us at apsjournal@ualberta.ca or visit our website at www.nativestudies.ualberta.ca/research/aboriginal-policy-studies-aps.

UNIVERSITY OF ALBERTA

FACULTY OF NATIVE STUDIES
Aboriginal Affairs and

Aboriginal Affairs and
Northern Development Canada

Affaires autochtones et Développement du Nord Canada 


\title{
Métis Issues on @IndigenousXca
}

\author{
Adam Gaudry \\ Assistant Professor, Department of Indigenous Studies, University of Saskatchewan
}

I was sitting at the front of the room at an Indigenous studies conference after delivering a paper on Métis identity. A colleague came up to me and says, "A lot of people tend think of Métis identity as a waypoint, or like a transfer station-like changing buses; it's where they wait in between becoming white or Indian."

It's true. And these comments encapsulate how a good many people understand who we are. In scholarly circles, it's now more widely understood that Métis identity and history are areas of study that emerge from the experience of an Indigenous people. Yet in most places, people so poorly understood that Métisness, that they imagine that Indigenous people would not willingly identify as Métis if they had other, "more authentic," First Nations.

Such a belief finds its origins in Canadian policy. Métis and non-Métis are constantly faced with a public discourse that equates Métis with "half-breed," rather than with the other Indigenous nations of North America. In Canada's long-standing assimilationist push, Métis were first transformed by policy into "half-breeds", a category significantly broader than the Métis Nation that included all those Indigenous people who did not fall under the legislative purview of the Indian Act, but were not considered white either. Several decades after this conglomeration was created, the term "half-breed" was deemed pejorative. The term was replaced with the more politically palatable term "Métis," but without regard for its original meaning of a national formation of Indigenous people who lived on the northern plains, sharing a common culture, possessing a collective sense of self, and referring to themselves as Métis.

In this new category, a lot of non-Métis "half-breeds" were remade as "Métis," even though many were, in fact, non-status Indians desirous to get back "into treaty" and their communities of origin, not join an already-existing Indigenous people with whom they may have had no prior relationship. This terminological shift, then, has left us with messy and unclear language, which has been internalized by Métis and non-Métis alike, fostering significant confusion about who is Métis and what this entails.

In the mid-twentieth century, the Métis intelligentsia, aware of this tendency, pushed back by stressing the inherent value in Métisness, fostering a sense of Métis pride, and using the slogan, "Proud to be Métis." This vision, tightly bound to Métis nationalism, sees the denigration of Métisness not as a failure of Métis people or Métis culture, but rather as the result of a colonial program designed to assimilate us. Since Métisness is something that is inherently valuable, legitimate, and desirable, Métis intellectuals have challenged the political rebranding of Métis as "half-breeds" or non-Indian (and non-Inuit) Indigenous people with ongoing public education. This discourse has been uncritically internalized in many public forums and remains normalized in many sectors of Canadian public policy discourse.

aboriginal policy studies, vol. 5, no. 1, 2015 
This public education has gone on for decades now, and a growing number of vocal young Métis are at its helm. Armed with a clear understanding of the history of Canadian colonialism, social justice organizing experience, and a desire to build a better world, this Métis intelligentsia is decolonial in its political orientation. One of the most visible of this new generation is Chelsea Vowel, proprietor of the widely read blog apihtawikosisan. com and co-host of the Métis in Space podcast. Vowel also oversees the Twitter account @ IndigenousXca. @IndigenousXca has a rotating weekly host, an Indigenous person with an innovative perspective and something to say. It is inspired by the original @IndigenousX account in Australia, started by Luke Pearson in 2012. In Canada, the @IndigenousXca account is widely followed (roughly 3,500 people when I was hosting), and its followers come from diverse walks of life.

In the summer of 2015, Vowel approached me to host a week-long discussion on Métis issues on @IndigenousXca. I accepted, knowing that for most of the account's followers, this would be the first time they would witness a sustained discussion of Métis issues. I wanted people to have the opportunity to see a robust conversation about Métis history, identity, and culture, from knowledgeable sources, and I was aware that many people following the account either had no idea who the Métis people are, or had only heard the old colonial tropes about Métis mixedness.

My first goal was to provide adequate context, ensuring that it was clearly understood that Métis have a definitive history. While a general policy category full of all mixed-raced Indigenous families that were not status Indians would be made up of groups of people with very little in common, Métis share a great many common experiences, and nothing demonstrates this like Métis history. Flashpoints often stand out: the Battle of Seven Oaks in 1816, the Red River Resistance of 1869-70, and the Saskatchewan Resistance of 1885. The telling of this history is important, since it reminds us that Métis were content to be Métis, and were willing to go to war to remain that way. These old Métis, our political, social, cultural, and economic elders, did not view their identity as a waypoint on a longer journey. This was who they were, and nobody was going to take that from them.

The most interactive portion of my time hosting was a series of "Twitterviews" with other Indigenous intellectuals. To balance out my area of knowledge with that of others, I interviewed Métis scholars, Métis literary critics, and Métis spiritual practitioners. Rob Innes and I discussed Métis-First Nations relationships, especially during the treaty era, which were much more amenable than we typically thing. I spoke with Jennifer Adese about Métis literature, its history, and the recent explosion in Métis children's books, and we developed an introductory reading list for those interested in reading Métis authors. In perhaps what was the most controversial topic (as it always is), Chris Andersen discussed the importance of respecting Métis peoplehood by clearly defining who the Métis people are. I also spoke to Chantal Fiola about the often-misunderstood topic of Métis spirituality, ranging from Indigenized Catholicism to Mdewin.

In general, this dialogue and the various tweets seemed to be well-received by the account's followers. There were a number of individuals who told me that they had 
learned more about Métis issues during this week than throughout their entire formal education. I don't doubt this, as educational institutions often fail to engage substantively with Métis issues. If this tells us anything, it is of the need for a more concerted effort to include Métis content in public schools and at the college and university level. There is also an obligation for Canadians to educate themselves on these matters, to seek out these sources and read the literature and the histories identified here and elsewhere in order to move beyond thinking about Métis as some inferior, in-between category. What my time on @IndigenousXca taught me was twofold: first, that basic knowledge about Métis issues is remarkably low; and second, that when confronted with Métis knowledge from authoritative sources, people who understand Indigenous issues seem generally interested in gaining a better understanding of the Métis people.

Perhaps we have the basic building blocks of a paradigm shift here, a way to move beyond an understanding of Métis identity as a policy category, or the place you go when you don't fit elsewhere. From here we can launch into more substantive discussions about Métis people today and the issues that affect us: the political marginalization, the poverty owing to dispossession, violent colonialism, and a significant policy gap. We have a treaty that has not been honoured, lands that were taken, lives that are restrained by injustice and inequality, and a nation-to-nation relationship with Canada that is repeatedly ignored. While none of these things will change through education alone, it can serve as a launch pad to challenge the more substantive injustices that face the Métis people. 
Here are some examples of Adam Gaudry's conversations as the @IndigenousXca host from June 18-25, 2015:

Hello everyone! My name is Adam Gaudry (@adamgaudry) and I'll be the @IndigenousXca host for the week.

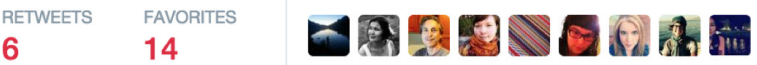

5:56 PM - 18 Jun 2015

h 난ㄱ․

Adam Gaudry @indigenousXca · Jun 18

I'm going to be tweeting mostly about Métis politics over the next week, and hopefully we'll have some good conversations about Metis issues
$\leftrightarrow$
낙 7
† 21
$\cdots$

2. Adam Gaudry @IndigenousXca. Jun 18

(1) Before we get too far into this, I think it's important to clarify who I mean when I use the term "Métis."
h
낙 3
$\star 7$

Adam Gaudry @IndigenousXca. Jun 18

There's a misguided perception that Métis identity is complicated, but I don't

think it's any more complicated than say Nuu-chah-nulth ID.
4
낙 4
$\star 5$
00

Adam Gaudry @indigenousXca. Jun 18

Métis are a people, with a common culture, common history, common

language(s), with a common self-awareness as Métis.
s
낙 10
$\star 9$
$\circ \circ$

Adam Gaudry @IndigenousXca. Jun 18

Although, Métis identity is complicated by a legal "Métis" identity that is accorded rights under the Cdn Constitution

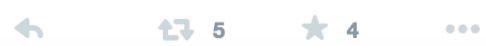


Adam Gaudry @|ndigenousXca. Jun 18

This is a lot like "Indian," which is not the same as being Gwich'in, so Canada's

legal Métis and being Métis are not the same thing either.
\&
낙ㄱ 7
$\star 4$

Adam Gaudry

@IndigenousXca · Jun 18

A

My point here is that Métis identity is defined by the Métis National Council

(@MNC_tweets) here: metisnation.ca/index.php/who-...
h
녹ㄱ 3
t 3

atihk $\infty @$ Marc_Lapensee · Jun 18

4 ling

OndigenousXca Can you give me a clear definition of Métis in one sentence?

h 172

Adam Gaudry @indigenousXca. Jun 18

@Marc_Lapensee Descended from Red River, the buffalo hunt, and the

communities these things created, related to other Métis.
8
눅 3
$+6$
000
View conversation

Adam Gaudry @IndigenousXca. Jun 18

This is the historic Metis Nation, which is more than just being mixed.

\& $476 \quad \star 5 \quad \ldots$

Adam Gaudry @indigenousXca. Jun 18

Métis as non-Indians in a legal sense, tend to occupy a difficult space in terms of Canadian government policy.
h
나 5
$\star 6$

Adam Gaudry @IndigenousXca. Jun 18

For example many Métis went to Indian residential schools, those set up specifically for Métis were defined as outside of the IRS settlement
h
274
$+3$
000

Adam Gaudry @indigenousXca. Jun 18

This means that many Métis continue to be ineligible for financial redress for the same genocidal policies:

albertametis.ca/MNAHome/News-A...

Adam Gaudry @indigenousXca. Jun 18

This has left Métis to deal primarily with the provinces--although this may change with the recent Daniels decision, on its way to the SCC.

h $473+200$ 
Adam Gaudry @indigenousXca · Jun 18

This means that Métis are typically impacted, but not directly targeted, by

federal policies. The feds therefore deny any legal liability.

$$
\text { h } 173 \ldots 0
$$

Adam Gaudry @IndigenousXca. Jun 18

As a result, most Métis cannot pursue redress through the federal government unless they were directly impacted by federal policy.

\& $273+2$

Adam Gaudry @indigenousXca. Jun 18

Métis can be caught between federal and provincial policies, like residential

schools and the 60s scoop. Métis were part of provincial progs

h 17 15 1560

Adam Gaudry @IndigenousXca · Jun 18

With residential schools, for example, Metis schools were not directly funded by

the feds, and therefore not considered an Indian Res School

\& 278 4 .

Adam Gaudry @IndigenousXca. Jun 18

The feds, wanting to limit their financial liability, deny responsibility for Metis students.

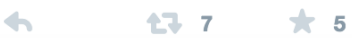

Adam Gaudry @indigenousXca.Jun 18

And other non-federally educated residential and day school students.

h 174 个 4 .

Adam Gaudry @indigenousXca. Jun 18

For me, this has always shown the tension between the ideal of reconciliation and the gov't desire to minimize the compensation for IRS.
4
177
† 4
000

Adam Gaudry @indigenousXca · Jun 18

If reconciliation was front and centre, the needs of all students in all genocidal schools, should be addressed. 
Adam Gaudry @IndigenousXca · Jun 23

One of the important areas we often neglect is Métis-First Nations relations--that is inter-Indigenous diplomacy.
\&
나 8
$\star 9$

Adam Gaudry @indigenousXca · Jun 23

Our focus on Indigenous-Canada political relationships are important, but so too is how we interact/interacted with each other.
h
는구 1
t 3

Adam Gaudry @IndigenousXca.Jun 23

My colleague and good friend @innes_rob is a professor in Indigenous Studies at @usask and wrote a book on prairie social relations.
h
는구 4
† 5

Adam Gaudry @indigenousXca · Jun 23

I wanted to talk to @innes_rob about the complexity of the relationships between prairie Indigenous peoples past and present.
\&
ㄴㄱ 3
$\star 5$
00

Adam Gaudry @indigenousXca. Jun 23

In Elder Brother and the Law of the People, you argue that doing "tribal

histories" (a history one one people) is difficult, why? @innes_rob
h
ㄴㄱㄱ 1
$\pm 2$

Rob Innes @innes_rob · Jun 23

@IndigenousXca Hi Adam When I researched the kinship patterns of S. SK FNs, the histories did not reflect their historic realities
4
난 1
\ 1

Rob Innes @innes_rob · Jun 23

@IndigenousXca Many bands had people from all 4 groups - including the Métis

h $271+1$

Adam Gaudry

@indigenousXca

\section{Following}

So the hard and fast distinctions we make about Métis/Cree/Assiniboine/Saulteaux weren't always in play historically? @innes_rob

$\begin{array}{lll}\text { RETWEetS } & \text { FAVORITE } \\ 2 & 1 & \text { aly }\end{array}$

12:20 PM - 23 Jun 2015

$$
4
$$


Adam Gaudry @IndigenousXca · Jun 23

Here's @innes_rob's great new book from @umanitobapress, Elder Brother and

the Law of the People: uofmpress.ca/books/detail/e...

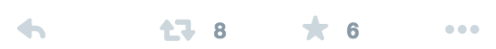

Adam Gaudry @IndigenousXca · Jun 23

Right now, @innes_rob is explaining the complexities of inter-Indigenous kinship/diplomacy/historic Métis-FN relationships

\& $171+2$

Rob Innes @innes rob · Jun 23

(1)Indigenous Xca So the Cree, Assiniboine, Saulteaux, and Métis were linked for economic, military and political reasons by kinship

s

2가 4

t 4

F. Adam Gaudry

(CIndigenousXca

Following

And in your book you argue that they never fought wars amongst one another, some call this the "Iron Alliance" @innes_rob
RETWEE
FAVORITE
1
1
国㛭
12:31 PM - 23 Jun 2015

Rob Innes @innes_rob - Jun 23

Q indigenous Xca So the Cree, Assiniboine, Saulteaux, and Métis were linked for economic, military and political reasons by kinship

4

나 4

th 4

A

Adam Gaudry

(B)IndigenousXca

;. Following

And in your book you argue that they never fought wars amongst one another, some call this the "Iron Alliance" @innes_rob
RETWEET FAVORITE
11
国载
12:31 PM - 23 Jun 2015 
Rob Innes @innes rob · Jun 23

@indigenousXca That the Métis are supposed to be culturally and racially

distinct from FNs acts to mask their deep kinship relations

4 274 \& 6

Adam Gaudry

IndigenousXca

Following

A clear distinction between Métis and Fns also suited/suits government policy categories@innes_rob

FAVORITES

2

12:49 PM - 23 Jun 2015

Rob Innes @innes_rob - Jun 23

@indigenousXca Métis and FNs were closely related. Motherers, fathers, sister, brothers, etc would switch bands constantly to each other

\& $274+3$

Adam Gaudry

@indigenous Xca

In the 1870 s and 1880s the line between

Treaty Indians and Métis was unclear in

Sask. Many could be either, chose

strategically @innes_rob

FAVORITE

1

12:50 PM - 23 Jun 2015

\& $47 \quad$ t

Rob Innes @innes_rob · Jun 23

(1) IndigenousXca Some historians have pointed to the animosity that existed

between Métis and FNs to show their were not close

(h) 17 \$ 1 oed

Adam Gaudry

Following

@indigenousXca

And as I noted earlier, Métis fought with Cree warriors in 1885, and Dakota and Cree fought with Métis soldiers @innes_rob

FAVORITES

2 国䙵

12:52 PM - 23 Jun 2015 
Rob Innes @innes_rob · Jun 23

(B)IndigenousXca Some historians have pointed to the animosity that existed

between Métis and FNs to show their were not close

4

27. 1

t个 1

Adam Gaudry

Following

(B) IndigenousXca

And as I noted earlier, Métis fought with

Cree warriors in 1885, and Dakota and Cree fought with Métis soldiers @innes_rob

FAVOAITES

2

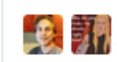

12:52 PM - 23 Jun 2015

\& 27

Rob Innes @innes_rob · Jun 23

(3) IndigenousXca many FNs people who were not satisfied with the reserve took

scrip instead and lived in Métis communities w/their relatives

4

274 ㄴ 3

Adam Gaudry

Following

My family did this quite a bit--there's

Gaudrys in Métis and FN communities

throughout Treaty 6 region @innes_rob

FAVORITES

3

\section{国国第}

1:01 PM - 23 Jun 2015 
Adam Gaudry @indigenousXca · Jun 23

I'm going to be chatting with @jenniferadese on Métis literature, which has made some important contributions to Aboriginal lit and CanLit

is 1 눈 12

Adam Gaudry @indigenousXca · Jun 23

Jennifer (@jenniferadese) is a Asst Professor at @Carleton_U's School of

Canadian Studies. She wrote her diss on Métis literature.

h 1700

Adam Gaudry @indigenousXca · Jun 23

So @jenniferadese, maybe we should start with Maria Campbell's Halfbreed, which for many (myself included) is our entry-point to Métis lit

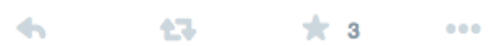

Adam Gaudry @indigenousXca - Jun 23

Check Halfbreed out here: amazon.ca/Half-Breed-Mar... and then buy it at a local independent bookstore. @jenniferadese

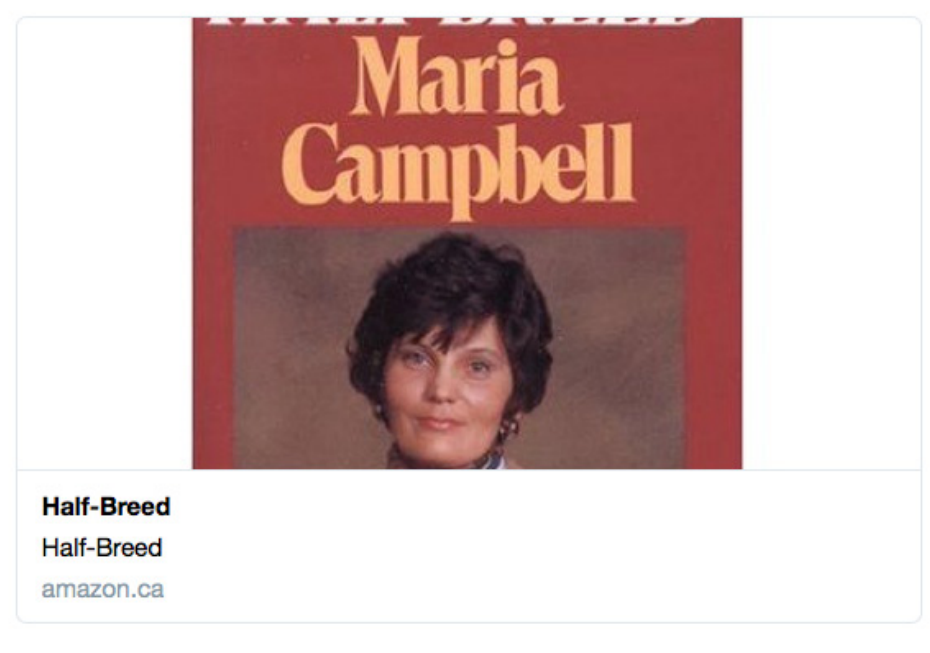

\section{Adam Gaudry @indigenousXca · Jun 23}

And @gregoryscofield's Thunder Through My Veins is kind of a Halfbreed for the next generation: amazon.ca/Thunder-Throug... @jenniferadese

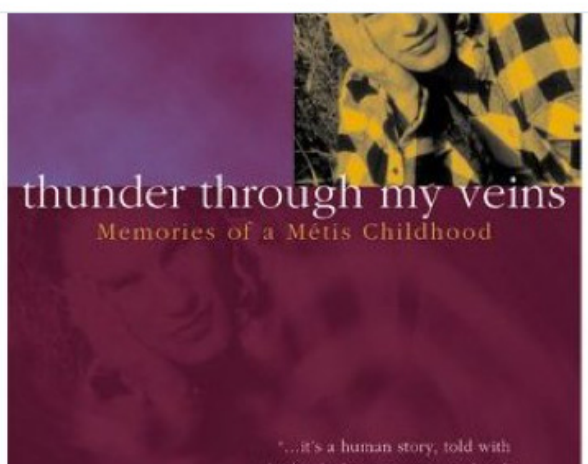

Thunder Through My Veins: Memories of a Metis Childhood Thunder Through My Veins: Memories of a Metis Childhood amazon.ca 
Adam Gaudry @indigenousXca · Jun 23

Check out this awesome write-up on Campbell's Halfbreed. Thanks Jacqueline!

Jacqueline Woods @JWoodsSK

@IndigenousXca @jenniferadese "Biography with Purpose," this provides an interesting background on its creation: hpcanpub.mcmaster.ca/casestudy/mar...

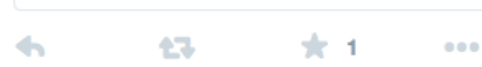

Adam Gaudry @IndigenousXca · Jun 23

A lot over the last 100 yrs has sought to scatter Métis communities, family is often the source of community, esp in the city @jenniferadese
is 13
000
View conversation

Adam Gaudry @IndigenousXca · Jun 23

Another interesting and politicized Métis biography: amazon.ca/Walking-Woods... @ @enniferadese (remember to support local booksellers)

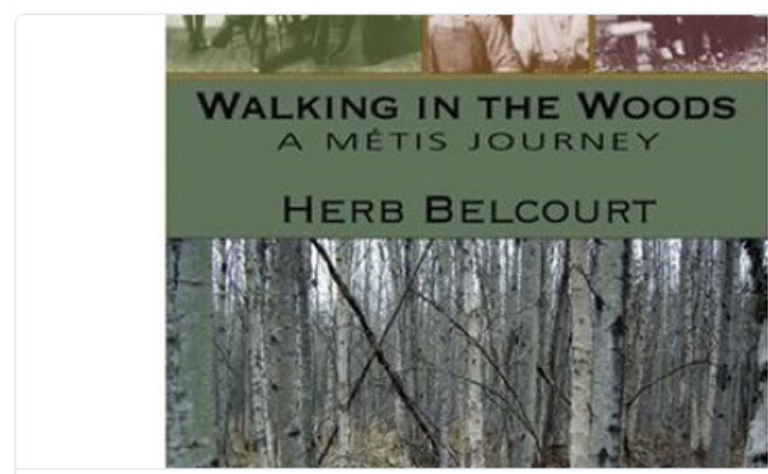

Walking in the Woods: A Métis Journey

Walking in the Woods: A Métis Journey

amazon.ca

h $\quad$ 나 $2 \quad \star 1 \quad \ldots$

Adam Gaudry @indigenousXca · Jun 23

which statistically speaking, is where most Métis live. More than FN and Inuit too. We're most urbanized Indigenous people @jenniferadese
क 27
000
View conversation

Adam Gaudry @indigenousXca · Jun 23

Some great titles (esp for kids) coming out of Pemmican too, @jenniferadese check them out: pemmicanpublications.ca
h 273
$\star 4$
.00
View conversation

Adam Gaudry @indigenousXca - Jun 23

There's a lot of great Métis lit out there, and Indigenous literature more generally is really taking off. I encourage you to check it out. 
So everyone please join me in welcoming @PhDFiola to the @IndigenousXca--as well as to twitter, since she just opened an account.

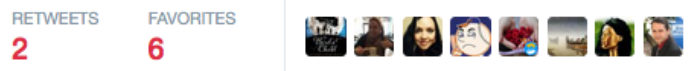

10:44 AM - 24 Jun 2015

h 17

Adam Gaudry (indigenousXca · Jun 24

So Chantal, why don't we start with a summary of the connection between Métis and Anishinaabe spirituality in S. Manitoba? @PhDFiola

\& $271+1$

View other replies

Chantal Fiola @PhDFiola · Jun 24

@IndigenousXca Grand Chief of the 3 Fires Midewiwin shared with me that Louis Riel was adopted by Midewiwin while in the US \& became Mide

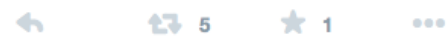

Adam Gaudry @indigenousXca · Jun 24

(aPhDFiola once again, there is not a hard and fast split between Métis people and their First Nations relatives historically speaking.

h $27+100$

Adam Gaudry @indigenousXca · Jun 24

So how does Métis spirituality work for you? How do you practice yours? @PhDFiola

h 27000

Chantal Fiola @PhDFiola · Jun 24

(a) IndigenousXca My family (like many) is disconnected from the teachings of our Indigenous ancestors so I (like many) have had to search
h
273
$+4$
000

Chantal Fiola @PhDFiola · Jun 24

@IndigenousXca I've been blessed to find teachers \& communities who welcomed me. I found home among the Midewiwin which historically...
4
272
to 2
000

Adam Gaudry @IndigenousXca · Jun 24

Chantal, this has been a great conversation, thanks so much for taking the time

to chat with me @PhDFiola

4

Chantal Fiola @PhDFiola · Jun 24

@IndigenousXca Miigwetch for chatting with me Adam; I've enjoyed my 1st ever Twitter convo!
4$$
27 .
$$ 
Adam Gaudry Retweeted

Adam Gaudry (QIndigenousXca · Jun 25

Anyway folks, it's been fun. But I'm signing off here. Follow me at @adamgaudry

and I'll be getting some twitterviews going there soon.
4
27. 1
\t 9

âpihtawikosisân favorited

Adam Gaudry @indigenousXca · Jun 25

My account is at @adamgaudry and I'd love to keep talking about Metis politics. 